\title{
The XP-pá-construction and V2
}

Jóhannes Gísli Jónsson

University of Iceland (Háskóli Íslands)

\begin{abstract}
This paper discusses a relatively unexplored construction in Icelandic that displays linear V3/V4 and I will refer to as the XP-pá-construction. In this construction, a left-peripheral adjunct is followed by adverbial $p a$ ' 'then' before the finite verb. The complementizer $a$ ' 'that' can occur between the adjunct and $p a \dot{a}$, an important fact that distinguishes the XP- $p a$-construction from the superficially similar så-construction in Norwegian and Swedish (Eide 2011; Holmberg 2018). It will be argued that $p a ́$ spells out the trace of the moved adjunct, following Grohmann's (2003) analysis of Copy Left Dislocation in German. This analysis entails that only one phrasal category moves to left periphery in the XP-pá-construction, as required by the Bottleneck Hypothesis (Haegeman 1996; Roberts 2004). The proposed analysis is also consistent with the view that the V2 constraint is satisfied in FinP, the lowest projection in the left periphery.
\end{abstract}

\section{Introduction}

Icelandic is known to be a fairly strict Verb Second (V2) language, displaying linear V2 in declaratives and wh-questions and embedded clauses as well as main clauses. The second fact sets Icelandic apart from the Mainland Scandinavian languages whereas the first one provides a contrast to partial V2 languages like Modern English. In spite of this, Icelandic has a number of constructions that exhibit linear V3 or V4 although they have not received much attention in the theoretical literature. This can be seen e.g. in clausal exclamatives (Jónsson 2010, 2017).

Ken Ramshøj Christensen, Henrik Jørgensen \& Johanna L. Wood (eds.). 2019.

The Sign of the V-Papers in Honour of Sten Vikner.

Dept. of English, School of Communication \& Culture, Aarhus University, pp. 341-360, doi:10.7146/aul.348.102. (C) The author(s). 
In this paper, I will discuss an understudied construction that features linear V3/V4 and where a left-peripheral adjunct is followed by adverbial $p a$ ' 'then' before the finite verb. In addition, the complementizer $a$ d 'that' may optionally intervene between the adjunct and $p a ́$. For convenience, I will refer to this as the XP-pá-construction. The left-peripheral adjunct and the adverbial $p a ́$ will be referred to as the antecedent and resumptive $p a ́$, respectively, although this is a fairly broad and non-standard use of these terms.

The XP-pá-construction is exemplified in (1), where the comma marks the short intonation break that often separates the antecedent from the rest of the clause. ${ }^{1}$ These examples display linear V4 or V3 depending on the presence or absence of the complementizer $a \partial^{2}$

(1) a. Vegna óveðurs, (að) pá var leiknum frestað due.to bad.weather that $D \dot{A}$ was the.game postponed 'Because of bad weather, the game was postponed.'

b. Samkvæmt nýjustu rannsóknum, (að) pá er kaffi gott í hófi according.to the.latest research that $P A$ is coffee good in moderation 'According to the latest research, coffee is good in moderation.'

c. Eins og ég hef áđur sagt, (að) pá eru allir velkomnir as $I$ have before said that $\mathrm{DA}$ are all welcome

'As I have said before, everybody is welcome.'

d. Á morgun, (að) pá verða tónleikar í Laugardalshöll tomorrow that $P \dot{A}$ will.be concert in Laugardalshöll

'Tomorrow, there will be a concert in Laugardalshöll Arena.'

My analysis of the XP-pá-construction will be cast within the cartographic approach to the left periphery, initiated by Rizzi (1997). The data discussed here clearly call for an expanded CP-domain to host all the different items

1 There is clearly some variation in this as neither Thráinsson (2005: 577-578) nor Rögnvaldsson (1982: 65-69) puts a comma after the antecedent in their examples of the XP-pá-construction.

2 Linear V5 is possible if resumptive $p a ́$ is immediately followed by certain adverbs, e.g. bara 'just', kannski 'maybe' and náttúrulega 'of course'. However, no adverb can intervene between $a ð$ and $p a ́$. 
preceding the finite verb. I assume that the XP-pá-construction satisfies the V2 constraint as the finite verb moves to check the verbal feature of Fin and Fin has its EPP feature checked through a phrasal category in Spec,Fin (Roberts 2004; Holmberg to appear). This means that the finite verb must follow the phrase in Spec,Fin and all deviations from linear V2 must be due to syntactic elements above FinP; see further discussion in 4.3 below.

To the best of my knowledge, the presence or absence of $a$ ð makes no difference for the syntactic or semantic properties of the XP- $p a$-construction but the possibility of placing $a$ d between the antecedent and resumptive $p a \dot{ }$ gives an important clue about the status of $p a$ and the structure of the XP$p a$-construction. It is interesting to note that the superficially similar $s \dot{a}$ construction in Norwegian and Swedish does not allow a complementizer before $s a ̊$ :

(2) a. I morgon så har vi öppet som vanligt (Swedish, Holmberg 2018: 30) tomorrow SA have we open as usual

'Tomorrow, we are open as usual.'

b. * I morgon att så har vi öppet som vanligt (Filippa Lindahl, p.c.) tomorrow at SA have we open as usual

This suggests that $s a ̊$ heads a projection hosting the antecedent as a specifier (see Eide 2011; Holmberg 2018 for an analysis of this kind). By contrast, I will argue that $p a ́$ is not a functional head in the CP-domain but rather a full phrase that spells out the trace of the antecedent, following Grohmann's (2003) analysis of Copy Left Dislocation in German. As discussed in more detail below, this derives many important facts about the XP-páconstruction, including restrictions on possible antecedents. The proposed analysis will also be shown to be consistent with the view that the V2 constraint is satisfied in FinP, the lowest projection in the left periphery.

\section{The basic facts}

In this section, the basic syntactic facts about the XP-pá-construction will be reviewed, i.e. restrictions on possible antecedents as compared to the $s a ̊$-construction in Norwegian and Swedish and similarities with Copy Left Dislocation. However, I will not be concerned with the pragmatics of this construction and how it might differ from topicalization (but see Eide 2011; 


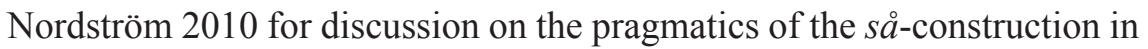
Norwegian and Swedish).

\subsection{The adjunct restriction}

The antecedent in the XP- $p a$-construction must be an adjunct of some kind. Thus, DP, PP and clausal arguments are excluded as well as predicative phrases even though all these elements undergo topicalization in Icelandic (see Einarsson 1949: 174, Thráinsson 2005: 577-578; Rögnvaldsson 1982: 65-69). In addition, negative adjuncts, including clausal negation, cannot be antecedents in the XP- $p a ́$-construction:

(3) a. * Dessa mynd, (að) pá hafa flestir séð

this movie that $D \dot{A}$ have most seen

'This movie, most people have seen.'

b. * Hvaðan pessi hugmynd kemur, (að) pá veit ég ekki where.from this idea comes that $P \dot{A}$ know $I$ not

'Where this idea comes from, I don't know.'

c. * Drykkjumaður, (að) pá hefur hann lengi verið drinker that $P A$ has he long been

'A heavy drinker, he has been for a long time.'

d. * Ekki, (að) pá hafa nemendur stolið ostinum not that $P A$ have students stolen the.cheese

'Students have not stolen the cheese.'

e. * Á engan hátt, (að) pá vil ég gera lítið úr in no way that $D \dot{A}$ want I make little out.of this 'In no way do I want to treat this lightly.'

In contrast to these examples, the corresponding examples with topicalization are fully acceptable as shown in (4): ${ }^{3}$

3 Admittedly, predicative NPs are rarely fronted in Icelandic and examples of this kind have a highly formal flavor. The crucial point here, though, is that there is a clear contrast between (3c) and (4c). 
(4) a. bessa mynd hafa flestir séð

this movie have most seen

'This movie, most people have seen.'

b. Hvaðan pessi hugmynd kemur veit ég ekki where.from this idea comes know I not

'Where this idea comes from, I don't know.'

c. Drykkjumaður hefur hann lengi verið drinker has he long been

'A heavy drinker, he has been for a long time.'

d. Ekki hafa nemendur stolið ostinum not have students stolen the.cheese 'Students have not stolen the cheese.'

e. Á engan hátt vil ég gera lítið úr in no way want I make little out.of this 'In no way do I want to treat this lightly.'

A further restriction is that $w h$-phrases cannot be antecedents, including wh-adjuncts. This is exemplified in (5) below.

a. * Hvers vegna, (að) pá var leiknum frestað? why that $P \dot{A}$ was the.game postponed

'Why was the game postponed?'

b. * Samkvæmt hvaða rannsóknum, (að) pá er kaffi gott í hófi? according.to which research that $P A$ is coffee good in moderation 'According to which research is coffee good in moderation?'

c. * Hvenær, (að) pá verða tónleikar í Laugardalshöll? when that $P A$ will.be concert in Laugardalshöll 'When will there be a concert in Laugardalshöll Arena?'

Anticipating the analysis presented in section 4, I take these examples to show that resumptive $p a ́$ lacks the features [+wh] to match wh-antecedents 
and $[+$ neg] to match negative antecedents. There is also a feature mismatch in (3a-c) but these examples can be salvaged by the appropriate resumptive proforms (see examples in 2.3 below).

\subsection{The XP-pá-construction vs. the så-construction}

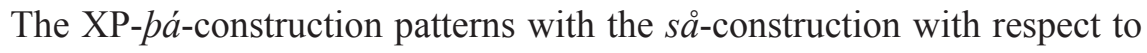
examples like (3) - (5) (see Nordström 2011; Eide 2011; Holmberg 2018 and references cited there). ${ }^{4}$ However, possible antecedents are more restricted in the XP-pá-construction and this is most clearly seen in that

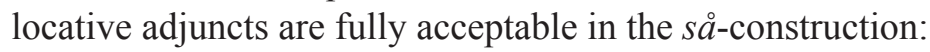

(6) I byen så trefte eg nokre kamerater (Faarlund 1980: 123) in town SA met I some buddies

'In town, I met some buddies.'

This is not the case for the XP- $p a$-construction as shown by the following example from Rögnvaldsson (1982: 218):

(7) ?? Á Akureyri, (að) pá eru fjöldamörg söfn in Akureyri that $D \dot{A}$ are quite.many museums 'In Akureyri, there are a lot of museums.'

If $p a$ is replaced by the locative adverb par 'there', this example becomes fully acceptable:

(8) Á Akureyri, (að) par eru fjöldamörg söfn in Akureyri that there are quite.many museums 'In Akureyri, there are a lot of museums.'

Salvesen (to appear) divides adverbial resumptives in Germanic into two classes, specialized remsumptives and generalized resumptives. She claims that Icelandic $p a ́$ belongs to the first class whereas Norwegian and Swedish så falls into the second one. While resumptive pá is more restrictive with respect to possible antecedents than resumptive $s a$, it is hardly very specialized. Salvesen's view seems to rest on the assumption

4 An exception is Fenno-Swedish, which allows all kinds of antecedents with resumptive så; see Holmberg (2018) for examples and discussion. 
that $p a ́$ cannot resume what she calls general adverbials but this does not accord with my judgments. ${ }^{5}$ This can be seen e.g. in (1a-b). As further illustrated in (9), I find adjunct phrases like pess vegna 'therefore' or samt sem áđur 'nevertheless' fully acceptable as antecedents of resumptive $p a ́$ :

(9) a. Pess vegna, (að) pá erum við hér í kvöld therefore that $P \dot{A}$ are we here tonight

'Therefore, we are here tonight.'

b. Samt sem áður, (að) pá hefur enginn afsannað pessa kenningu nevertheless that $D A$ has nobody disproved this theory 'Still, nobody has falsified this theory.'

Of course, my judgments on resumptive $p a ́$ may be more liberal than those of the native speakers that Salvesen consulted. It is also possible that native speakers reject examples like $(9 a-b)$ when they see them in written form because resumptive $p a ́$ is very much a trait of spoken Icelandic, especially with non-clausal antecedents. It is also worth noting that a search in the Risamálheild Corpus (on August 10, 2019) returns 114 examples of samt sem áður 'nevertheless' as an antecedent in the XP-pá-construction, including 106 examples without að, but only 19 examples with pess vegna 'therefore', including 16 without að. This suggest that there might be speakers who find (9b) more acceptable than (9a).

\subsection{The XP-pá-construction and Copy Left Dislocation}

The XP-pá-construction in Icelandic is like Copy Left Dislocation (CLD) in that a left-peripheral constituent is followed by a resumptive proform. ${ }^{6}$ Moreover, the complementizer ad can occur before the resumptive proform, although this is rather uncommon with CLD and marginal if the left-peripheral constituent is an object DP. This can be seen in the following examples, which are identical to the examples in (3a-c) except that $p a ́$ has

5 Still, I agree with her claim that the XP- $p a$-construction, in contrast to the $s a ̊$-construction, does not allow the proximal adverbial nú 'now' as an antecedent. Note, however, that núna 'now' is a possible antecedent, but this may have to do with the fact that núna has a purely temporal interpretation whereas nú has some other uses, e.g. as a discourse particle.

6 The terms Copy Left Dislocation and Hanging Topic Left Dislocation as used here correspond to the older terms Contrastive Left Dislocation and Left Dislocation, respectively. 
been replaced by an appropriate resumptive proform, hana 'her' in (10a) and $p a \partial^{\text {' }}$ it' in (10b-c):

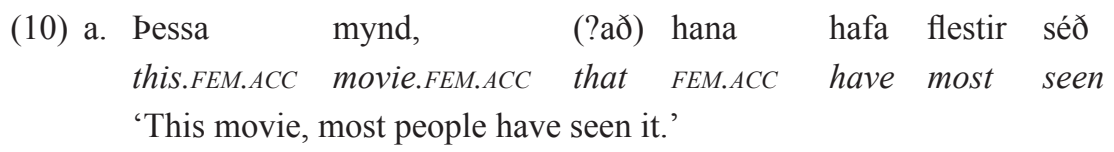

b. Hvaðan pessi hugmynd kemur, (að) pað veit ég ekki where.from this idea comes that it know I not

'Where this idea comes from, I don't know that.'

c. Drykkjumaður, (að) pað hefur hann lengi verið drinker that it has he long been 'A heavy drinker, that he has been for a long time.'

The contrast between (10a-c) and (3a-c) shows that resumptive pá is an adjunct and thus incapable of resuming arguments and predicates. A resumptive proform in CLD must match the gender, number and case of a DP argument, as in (10a), but for complement clauses and predicative phrases, the appropriate proform is the unmarked neuter pronoun bað, as in (10b-c).

The examples in (3a-c) and (10a-c) suggest that að occupies a head position in the CP-domain, whose specifier is either the antecedent of the $\mathrm{XP}$ - $b a$-construction or a copy-left-dislocated element. Thus, the conclusion is that both constructions share the same basic structure (but see section 4.3 for details).

The similarities between the XP-pá-construction and CLD are also reflected in their syntactic distribution. As shown by the following example from Thráinsson (1979: 64), CLD can occur in clauses embedded under bridge verbs like segja 'say':

(11) Jón segir að pessum hring, honum hafi Ólafur
John says that this.MASC.DAT
lofarg.MASC.DAT MASC.DAT has Olaf
promised Mary
'John says that this ring, Olaf has promised it to Mary.'


The XP-pá-construction patterns with CLD in this respect. One representative example of this from the Risamálheild Corpus is shown below:

(12) við erum nú að vonast til pess að með meiri tíma og betra samtali, we are now to hope to it that with more time and betterdiscussion að pá leysi menn petta nú that $P \dot{A}$ solve people this now

'We are now hoping that, with more time and improved negotiations, this will be solved.'

With non-bridge verbs in the matrix clause, both CLD and the XP-páconstruction are degraded:

(13) a.?? Jón efast um að pessum hring, honum hafi Ólafur Johndoubts that this.MASC.DAT ring.MASC.DAT MASC.DAT has Olaf lofað Maríu promised Mary

'John doubts that this ring, Olaf has promised it to Mary.'

b.?? Ég efast um að samkvæmt rannsóknum, (að) pá sé kaffi gott $I$ doubt that according.toresearch that $P \dot{A}$ is coffee good í hófi in moderation

'I doubt that according to research, coffee is good in moderation.'

This shows that the XP- $p a$-construction and CLD behave very much alike with respect to embeddability. Embedded topicalization in Icelandic is also sensitive to the contrast between bridge and non-bridge verbs (see Angantýsson 2011 for an in-depth investigation) but I will have nothing further to say about this here.

Hanging Topic Left Dislocation (HTLD) differs from CLD with respect to the properties discussed above. As illustrated in (14) (from Thráinsson 1979: 63), HTLD is not possible in subordinate clauses even if they are complements of a bridge verb. 

(14) * Jón segir að pessi hringur, Ólafur hafi lofað John says that this.MASC.NOM ring.MASC.NOM Olaf has promised Maríu honum
Mary MASC.DAT
'John says that this ring, Olaf has promised it to Mary.'

HTLD is also incompatible with the complementizer $a$. This is exemplified in (15) where the dislocated nominative DP resumed by a non-nominative pronoun in situ is an unambiguous marker of HTLD (see Thráinsson 1979: 59-70 on the contrast between CLD and HTLD in Icelandic):
Pessi mynd,
(*að) ég hugsa að flestir hafi séð hana this.FEM.NOM movie.FEM.NOM that $I$ think that most have seen FEM.ACC
'This movie, I think most people have seen it.'

Zaenen (1985: 4-20) argues that HTLD in Icelandic involves basegeneration of the hanging topic rather than movement. Since such topics occupy a very high position in the left periphery (see 4.3 below), the ungrammaticality of (15) suggests that it is too high to fulfill the requirement of the complementizer $a \partial$ to have its specifier position filled.

\section{Movement vs. base-generation}

In this section, the issue of movement vs. base-generation of the adjunct antecedent and resumptive $p a$ will be addressed. ${ }^{7}$ I will argue that the adjunct antecedent undergoes movement out of TP and this is the only movement that takes place.

Resumptive $p a$ s shows no evidence of movement to the C-domain. As Rögnvaldsson (1982: 66-67) points out, resumptive $p a ́$ cannot occur inside $\mathrm{TP}$, as shown in (16b-c).

(16) a. Ef petta gengur vel, pá gerum við lengri samning if this goes well $P A ́$ make we longer contract 'If this goes well, we will extend the contract.'

b. * Ef petta gengur vel, gerum við pá lengri samning if this goes well make we $P \dot{A}$ longer contract

\footnotetext{
$\overline{7}$ I prefer the more traditional terms movement and base-generation to the Minimalist terms internal and external merge but this does not entail any theoretical committment on my behalf.
} 
c. * Ef petta gengur vel, gerum við lengri samning $\mathrm{PÁ}$ if this goes well make we longer contract pá

Turning to the adjunct antecedent, there is clear evidence of movement as seen by reconstruction effects with respect to Binding Principles A and B:
a. María ${ }_{i}$ lagaði eldhúsið með hjálp mömmu sinnar $_{i} /{ }^{*}$ hennar $_{i}$ Mary fixed the.kitchen with help mother REFL/her
'Mary fixed the kitchen with the help of her mother.'

b. Með hjálp mömmu sinnar ${ }_{i} /$ hennar $_{\mathrm{i}}$ að pá lagaði

With help mother REFL/her (that) $D A$ fixed

María $_{i}$ eldhúsið

Mary the.kitchen

The reflexive possessive in (17a) inside the PP adjunct obeys Principle A since it is bound by a clause-mate subject and the pronoun inside the same adjunct violates Principle B by being bound by the subject. As shown in (17b), movement of this PP to the left periphery makes no difference for binding: The reflexive still satisfies Principle A and the pronoun violates Principle B. Thus, the PP in (17b) behaves as if it had not moved out of TP at all.

The adjunct antecedent can also have an embedded reading. For instance, the temporal phrase á morgun 'tomorrow' denotes the time of John's birthday in (18b), just as in (18a). Due to the present tense in the matrix clause, there is no other possible interpretation of $(18 \mathrm{~b})$. This is clear evidence that á morgun is base-generated inside the embedded clause in (18b).

(18) a. Ég held að Jón eigi afmæli á morgun I think that John has birthday tomorrow 'I think that John has a birthday tomorrow.'

b. Á morgun, (að) pá held ég að Jón eigi afmæli tomorrow that $D A$ think I that John has birthday

'Tomorrow, I think that John has a birthday.' 
It should also be noted that the antecedent shows sensitivity to strong islands, a traditional diagnostic of movement. This is exemplified in (19ab):

(19) a. Ég var veikur meðan María lagaði eldhúsið með hjálp Siggu I was sick while Mary fixed the.kitchen with help Sigga's

b. * Með hjálp Sigga (að) pá var ég veikur meðan María With help Sigga's that PÁ was I sick while Mary lagaði eldhúsið fixed the.kitchen

The critical example here is (19b), which is derived by movement of the adjunct PP (með hjálp Siggu) from a temporal clause. Since temporal clauses are strong islands, this example is expected to be ungrammatical.

With respect to the data illustrated in (16) - (19), the XP-pá-construction behaves very much like CLD in Icelandic. Thus, fronting the resumptive proform is strongly preferred to no movement (Thráinsson 1979: 67-68) and CLD in Icelandic also involves movement of the dislocated element, as shown by Zaenen (1985: 45-61). As discussed in section 4 below, these and other similarities between the XP- $p a ́$-construction and CLD make it possible to employ Grohmann's (2003) analysis of CLD in German to account for the basic properties of the XP- $p a$-construction.

\section{Analysis}

\subsection{The status of $p \dot{a}$}

The crucial issue to be addressed here is whether resumptive $p a ́$ occupies a head position or a specifier position in the left periphery in the XPpá-construction. Østbø (2006), Eide (2011), Holmberg (2018) argue that

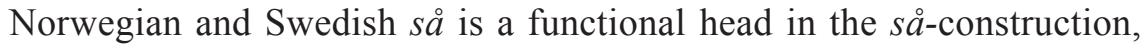
but this cannot be right for $p a ́$ for at least two reasons. First, $p a ́$ can easily receive full stress, in contrast to typical functional heads like the complementizer $a ð$ that precedes $p a ́$ or Norwegian and Swedish så in the $s a ̊$-construction. Second, $p a ́$ can be a clause-initial element triggering V2. This is true for all kinds of $p a ́$, including $p a ́$ expressing a consequence, as in (20a), or the addition to a list of previously mentioned propositions, as in (20b): 
(20) a. María sagði upp í gær. Pá hlýtur Hanna að gera pað líka Mary resigned yesterday then must Hanna to do it too 'Mary resigned yesterday. Then, Hanna must do the same.'

b. Jón hefur marga kosti. Hann er heiðarlegur og alltaf John has many good.qualities he is honest and always tilbúinn að hjálpa öðrum. Pá hefur hann ákaflega gott minni. ready to help others $P A$ has he incredibly good memory 'John has many good qualities. He is honest and always ready to help others. Moreover, he has an incredibly good memory.'

Moreover, the V2 constraint can be satisfied by fronting pá that refers to an adjunct and is therefore very similar to resumptive $p a ́$ :

(21) a. A: Hvernig unnu peir leikinn? how won they the.game

'How did they win the game?'

b. B: Með sterkum varnarleik with strong defensive play

c. A: En pá er allt hægt but $P A ́$ is everything possible

'But everything is possible with strong defensive play.'

As shown by the translation in (21c), pá is interpreted as referring to the $\mathrm{PP}$ in (21b). Moreover, the finite verb must immediately follow pá in (21c), yielding a V2 structure.

\subsection{The XP-pá-construction as CLD}

Having established that resumptive $p a ́$ is a full phrase, the next step is to determine the syntactic structure associated with the XP- $p a$-construction in Icelandic. In view of all the similarities between the XP- $p a$-construction and CLD that have been discussed, I will adopt a slightly modified version of Grohmann's (2003) analysis of CLD in German. The central points of this analysis are shown in (22), based on Grohmann (2003: 155), where RP stands for a resumptive proform: ${ }^{8}$

8 I have replaced Grohmann's CP, TopicP and IP by Force-TopicP, FinP and TP but this does not affect the essentials of the proposal. 
This configuration has two projections in the left periphery. I will follow Eide's (2011) analysis of the $s a$-construction by assuming head stacking in the highest projection, i.e. Force-Topic (see also Holmberg 2018). Force-TopicP hosts the clause-initial XP, the antecedent, as its specifier and the resumptive proform spells out the trace of the moved XP in the specifier of FinP. This follows from Grohmann's (2003) Anti-Locality Hypothesis, which proscribes phrasal movement within a prolific domain unless the relevant trace is phonetically realized. One of these domains is the CP-domain, the discourse layer hosting pragmatic features like topic and focus. The other two domains are the TP-domain, which determines agreement and the vP-domain, which defines thematic relations. AntiLocality requires the trace of the initial XP in (22) to be spelled out by a resumptive pronoun because the XP moves within the $\mathrm{CP}$-domain, i.e. from Spec,Fin to Spec,Force-Topic. ${ }^{9}$ Thus, resumptive structures arise because of movement that is too local in the sense of being within the same prolific domain.

The structure in (22) derives many important properties of the XP- $p a$ construction. First, since resumptive $p a ́$ is chain-linked to the antecedent, pá must be a full phrase just like the antecedent. That this prediction is borne out was already shown in 4.1. Second, it also follows that the antecedent can only be an adjunct. This is so because $p a ́$ lacks the appropriate features to spell out the trace of an argument or a predicate, as exemplified in (3ac). Moreover, as shown in (3d-e) and (5a-c), pá lacks the features [+neg] and $[+w h]$ to lexicalize the traces of negative adjuncts and wh-adjuncts, respectively. Third, the structure in (22) correctly rules out XP- $a$ d without pá but rules in XP-pá without $a ð$, as shown in (23):

(23) a. Á morgun, að pá verða tónleikar í Laugardalshöll tomorrow that $P \dot{A}$ will.be concert in Laugardalshöll

'Tomorrow, there will be a concert in Laugardalshöll Arena.'

b. Á morgun, pá verða tónleikar í Laugardalshöll tomorrow $P \dot{A}$ will.be concert in Laugardalshöll

\footnotetext{
$\overline{9}$ Note that pá may spell-out a trace of a fronted XP base-generated in Spec,Fin. This is presumably the right analysis for clause-initial adjuncts in the XP-pá-construction that do not originate within TP; see Holmberg (to appear) for discussion of some cases like that relating to the $s \stackrel{\circ}{\text {-construction. }}$
} 
c. * Á morgun, að verða tónleikar í Laugardalshöll tomorrow that will.be concert in Laugardalshöll

d. Á morgun verða tónleikar í Laugardalshöll tomorrow will.be concert in Laugardalshöll

The presence of $a ð$ in (23c) shows that this example cannot be analyzed as topicalization like (23d). This example violates Anti-Locality as the trace of the adjunct movement from Spec,Fin to Spec,Force-Topic is not overtly realized. By contrast, no principle of grammar is violated by the absence of $a$ in (23b); hence, the difference between (23b) and (23a) is just a matter of phonetic realization of the highest head in the XP- $p a$-construction.

At this juncture, it is worth pointing out one potential problem with the proposed analysis: Given the structure in (22) one might expect topicalization to involve CP-internal movement from Spec,Fin to Spec,Topic, but this would incorrectly predict that topicalization triggers resumption. One possible solution is to assume that Topic never projects independently in Icelandic; instead it always forms a complex head with the highest adjacent head in the CP-domain. On this view, the landing site for topicalization would be Spec,Topic-Fin with no further movement inside the $\mathrm{CP}$-domain but this will have to be an issue for future investigation.

\subsection{V2, FinP and the Bottleneck Hypothesis}

I have adopted here the common view that Fin, the lowest head in the articulated left periphery, is the landing site for the finite verb in V2 languages like Icelandic (Roberts 2004). Thus, the V2 requirement is fulfilled by (a) movement of the finite verb to Fin and (b) the checking of the EPP features of Fin in Spec,Fin (Holmberg 2015). There is strong evidence that the finite verb never moves beyond Fin in Icelandic. For one thing, it is a valid generalization for Icelandic and the other V2 languages that the finite verb in the CP-domain only moves to the left of the subject. This follows immediately if Fin is the landing site of the finite verb. Under a Force-V2 analysis, some auxiliary assumptions would be required to derive this generalization since a finite verb in Force precedes some specifier positions in the left periphery. Moreover, the XP-pá-construction shows quite clearly that the finite verb sits in a low position in the left periphery where it can be preceded by three elements, the adjunct antecedent, the complementizer $a ð$ and resumptive $p a ́$. 
The Force-V2 analysis mentioned above (see Poletto 2002; Walkden 2015; Wolfe 2016 among others) is plausible for V2 languages or varieties where (a) the finite verb may precede a subject in the CP-domain, or (b) only one phrase within ForceP can precede the finite verb. Since (b) does not hold in Icelandic, as shown by the XP- $p a$-construction, and there is no evidence for (a) that I know of, this is not a viable analysis of V2 in Icelandic (see also Holmberg to appear for arguments against the Force-V2 analysis for Swedish).

Despite the linear V3/V4 in the XP- $p a$-construction, the analysis in (22) entails that only the adjunct antecedent moves past the finite verb in this construction. This is consistent with the generalization that V2 languages only allow one phrase to move to the left periphery. To account for this ban, the so called Bottleneck Hypothesis has been proposed (Haegeman 1996; Roberts 2004; Holmberg to appear). This hypothesis dictates that all movement to the left periphery in V2 languages must pass through the lowest specifier position, Spec,Fin. Once a phrase has moved to Spec,Fin, no other phrase can move to the left periphery, thereby skipping Spec,Fin. Roberts (2004: 316-317) suggests that such a movement violates Relativized Minimality (Rizzi 1990) because the phrase in Spec,Fin, attracted by the EPP feature of Fin, would be an intervener for any kind of higher movement. Be that as it may, the analysis of the XP- $p a$-construction advanced here is consistent with the Bottleneck Hypothesis as the fronted adjunct moves through Spec,Fin on its way to Spec,Force-Topic.

The validity of the Bottleneck Hypothesis is shown e.g. by the fact that the XP-pá-construction is incompatible with wh-movement to a position between the antecedent and resumptive $p a ́$. This is exemplified in (24):

(24) a. * Á morgun, hvaða bók pá ætlar hann að lesa? tomorrow which book $P A$ intends he to read

b. * [Force-TopicP Á morgun ${ }_{i}\left[\right.$ FocusP hvaða bók [FinP pá ${ }_{i}\left[\right.$ Fin' V-Fin [TP....t $\left.\left.\left.\left.{ }_{i}\right]\right]\right]\right]$ ?

For concreteness, we can assume that the wh-phrase occupies Spec,Focus between Force-TopicP and FinP. In this configuration, the wh-phrase must have moved to the left periphery without stopping in Spec,Fin because that position hosts the trace of the moved antecedent, spelled out as pá. Thus, the wh-movement in (24) violates the Bottleneck Hypothesis. As shown in 
(25), this example is acceptable if the wh-phrase remains in situ, resulting in an echo-question:

(25) Á morgun, (að) pá ætlar hann að lesa hvaða bók? tomorrow that $P \dot{A}$ intends he to read which book

It must be stressed that the Bottleneck Hypothesis only restricts movement to the CP-domain. Thus, it is possible to combine HTLD with the XP-páconstruction, as in (26) below, because the only phrase moved to the left periphery in such examples is the adjunct antecedent. The hanging topic is base-generated in a position above ForceP, e.g. in the Frame field of Beninca \& Poletto (2004).

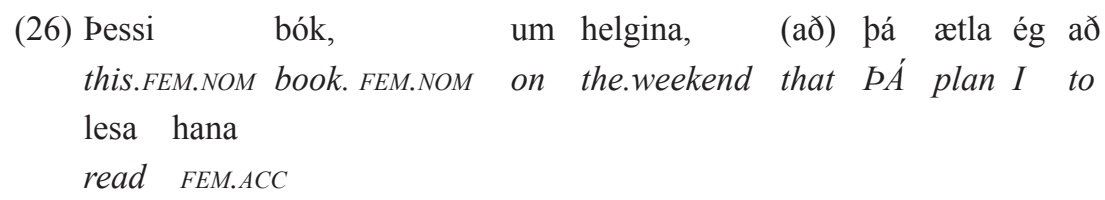

'This book, over the weekend I plan to read it.'

Although examples like (26) are clearly rather stilted, presumably due to the number of maximal projections preceding the finite verb, they sound grammatical to me. As shown in (27), the base position of the hanging topic is too high for it to follow the adjunct XP:

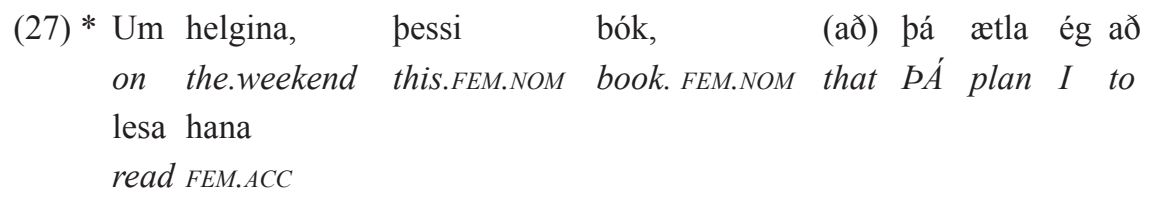

Theoretically, it should also be possible to base-generate more than one phrasal category above Spec,Force-Topic. I am not sure about the acceptability of this option in Icelandic but see e.g. Grohmann (2003) on HTLD stacking in German.

\section{Conclusion}

In this paper, the basic properties of the XP-pá-construction in Icelandic have been presented. This construction has been shown to be very similar 


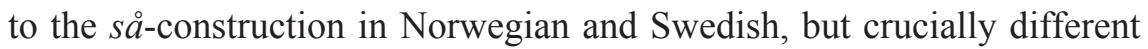
in that the complementizer $a$ may occur between the fronted adjunct and resumptive $p a ́$. I have argued that $p a ́$ is a full phrase, spelling out the trace of the moved adjunct in Spec,Fin, following Grohmann's (2003) analysis of Copy Left Dislocation in German. The adjunct moves to a position that has been identified as Spec,Force-Topic where it may be followed by complementizer að. This analysis is consistent with the view that V2 is satisfied in the lowest projection of the left periphery and the Bottleneck Hypothesis, which blocks movement of more than one phrasal category to the left periphery in V2 languages.

\section{References}

Angantýsson, Ásgrímur. 2011. The syntax of embedded clauses in Icelandic and related languages. Reykjavík: Hugvísindastofnun.

Beninca, Paola \& Cecilia Poletto. 2004. Topic, focus, and V2: Defining the sublayers. In Luigi Rizzi (ed.) The cartography of syntactic structures (volume 2): The structure of CP and IP, 52-75. New York \& Oxford: Oxford University Press.

Eide, Kristin M. 2011. Norwegian (non-V2) declaratives, resumptive elements, and the Wackernagel position. Nordic Journal of Linguistics 14. 179-213. doi:10.1017/S0332586511000163.

Einarsson, Stefán. 1949. Icelandic. Grammar. Texts. Glossary. Baltimore: The Johns Hopkins Press.

Faarlund, Jan Terje. 1980. Norsk syntaks i funksjonelt perspektiv. Ny revidert utgåve. Oslo: Universitetsforlaget.

Grohmann, Kleanthes K. 2003. Prolific domains: On the anti-locality of movement dependencies. Amsterdam: Benjamins. https://doi.org/10.1075/la.66.

Haegeman, Liliane. 1996. Verb Second, the split CP and null subjects in early Dutch finite clauses. GenGenP 4(2). 135-175. [Available online at: http://ling. auf.net/lingBuzz/001059]

Holmberg, Anders. 2015. Verb second. In Tibor Kiss \& Artemis Alexiadou (eds.), Syntax - an international handbook of contemporary syntactic research, 343-384. [2nd edition, HSK Series.] Berlin: Mouton de Gruyter. https://doi. org/10.1515/9783110377408.342.

Holmberg, Anders. 2018. The syntax of the V3 particle så in the Swedish left periphery. Working Papers in Scandinavian Syntax 101. 29-48. 
Holmberg, Anders. To appear. On the bottleneck hypothesis in Swedish. In Rebecca Woods, Sam Wolfe \& Theresa Biberauer (eds.), Rethinking verb second. New York and Oxford: Oxford University Press.

Jónsson, Jóhannes G. 2010. Icelandic exclamatives and the structure of the CP layer. Studia Linguistica 64. 37-54. https://doi.org/10.1111/j.14679582.2010.01169.x.

Jónsson, Jóhannes G. 2017. Discourse particles and hvað-exclamatives. In Josef Bayer \& Volker Struckmeier (eds.), Discourse particles. Formal approaches to their syntax and semantics, 100-114. [Linguistische Arbeiten 564.] Berlin: Mouton de Gruyter. https://doi.org/10.1515/9783110497151-005

Nordström, Jackie. 2010. The Swedish så-construction, a new point of departure. Working Papers in Scandinavian Syntax 85. 37-63.

Østbø, Christine B. 2006. The Norwegian function word så and Norwegian $\mathrm{CP}$ syntax. A talk given at the Workshop on inversion and verb movement, University of Tromsø.

Poletto, Cecilia. 2002. The left-periphery of V2-Rhaetoromance dialects: a new view on V2 and V3. In Sjef Barbiers, Leonie Cornips \& Susanne van der Kleij (eds.), Syntactic microvariation, 214-242. Amsterdam: Meertens Institute.

Rizzi, Luigi. 1990. Relativized minimality. Cambridge, Mass.: The MIT Press.

Rizzi, Luigi. 1997. The fine structure of the left periphery. In Liliane Haegeman (ed.), Elements of grammar, 281-337. Dordrecht: Kluwer. https://doi. org/10.1007/978-94-011-5420-8_7.

Roberts, Ian. 2004. The C-system in Brythonic Celtic languages, V2, and the EPP. In Luigi Rizzi (ed.), The cartography of syntactic structures (volume 2): The structure of CP and IP, 297-327. New York \& Oxford: Oxford University Press. https://doi.org/10.1353/lan.2019.0008.

Rögnvaldsson, Eiríkur. 1982. Um orðaröð og fcerslur i islensku. [On word order and movement in Icelandic.] MA-thesis, University of Iceland.

Salvesen, Christine M. To appear. Resumptive particles and verb second. In Rebecca Woods, Sam Wolfe \& Theresa Biberauer (eds.), Rethinking Verb Second. New York and Oxford: Oxford University Press.

Steingrímsson, Steinpór, Sigrún Helgadóttir, Eiríkur Rögnvaldsson, Starkaður Barkarson \& Jón Guðnason. 2018. Risamálheild: A very large Icelandic text corpus. Proceedings of LREC 2018, 4361-4366. Myazaki, Japan.

Thráinsson, Höskuldur. 1979. On complementation in Icelandic. New York: Garland Publishing.

Thráinsson, Höskuldur. 2005. Færslur og formgerðir. In Höskuldur Thráinsson (ed.), Setningar: handbók um setningafrceði (Íslensk tunga III), 545-600. Reykjavík: Almenna bókafélagið. 
Walkden, George. 2015. Verb-third in early West Germanic: a comparative perspective. In Theresa Biberauer \& George Walkden (eds.), Syntax over time, 236-248. New York \& Oxford: Oxford University Press. https://dx.doi. org/10.1093/acprof:oso/9780199687923.003.0014.

Wolfe, Sam. 2016. A comparative perspective on the evolution of Romance clausal structure. Diachronica 33 (4). 461-502. doi 10.1075/dia.33.4.02wol.

Zaenen, Annie E. 1985. Extraction rules in Icelandic. New York \& London: Garland Publishing Inc.

\section{Acknowledgements}

I am indebted to Filippa Lindahl and an anonymous reviewer for constructive feedback on the first version of this paper. 